\title{
Corrigendum: PTEN: A Thrifty Gene That Causes Disease in Times of Plenty?
}

\section{OPEN ACCESS}

Edited and reviewed by:

Maurizio Muscaritoli,

Sapienza University of Rome, Italy

*Correspondence:

Ajit Venniyoor

avenniyoor@gmail.com

Specialty section: This article was submitted to

Clinical Nutrition,

a section of the journal

Frontiers in Nutrition

Received: 17 June 2020 Accepted: 19 October 2020 Published: 17 November 2020

Citation:

Venniyoor A (2020) Corrigendum: PTEN: A Thrifty Gene That Causes

Disease in Times of Plenty? Front. Nutr. 7:573536.

doi: 10.3389/fnut.2020.573536

\section{Ajit Venniyoor* \\ Department of Medical Oncology, National Oncology Centre, The Royal Hospital, Muscat, Oman}

Keywords: PTEN (phosphatase and tensin homolog deleted on chromosome 10), thrifty gene hypothesis, insulin resistance, carcinogenesis, polycystic ovarian disease (PCOD), diabetes mellitus, NAFLD

\section{A Corrigendum on}

PTEN: A Thrifty Gene That Causes Disease in Times of Plenty?

by Venniyoor, A. (2020). Front. Nutr. 7:81. doi: 10.3389/fnut.2020.00081

In the original article, there was a mistake in ${ }^{* *}$ Figure $1^{* *}$ as published.

** The caption in Box 6 (from top, right branch) reads "INCREASED THERMOGENESIS"**. The corrected ${ }^{* *}$ Figure $\mathbf{1}^{* *}$ appears below.

The caption should read "DECREASED THERMOGENESIS".

The authors apologize for this error and state that this does not change the scientific conclusions of the article in any way. The original article has been updated.

Copyright $\odot 2020$ Venniyoor. This is an open-access article distributed under the terms of the Creative Commons Attribution License (CC BY). The use, distribution or reproduction in other forums is permitted, provided the original author(s) and the copyright owner(s) are credited and that the original publication in this journal is cited, in accordance with accepted academic practice. No use, distribution or reproduction is permitted which does not comply with these terms. 


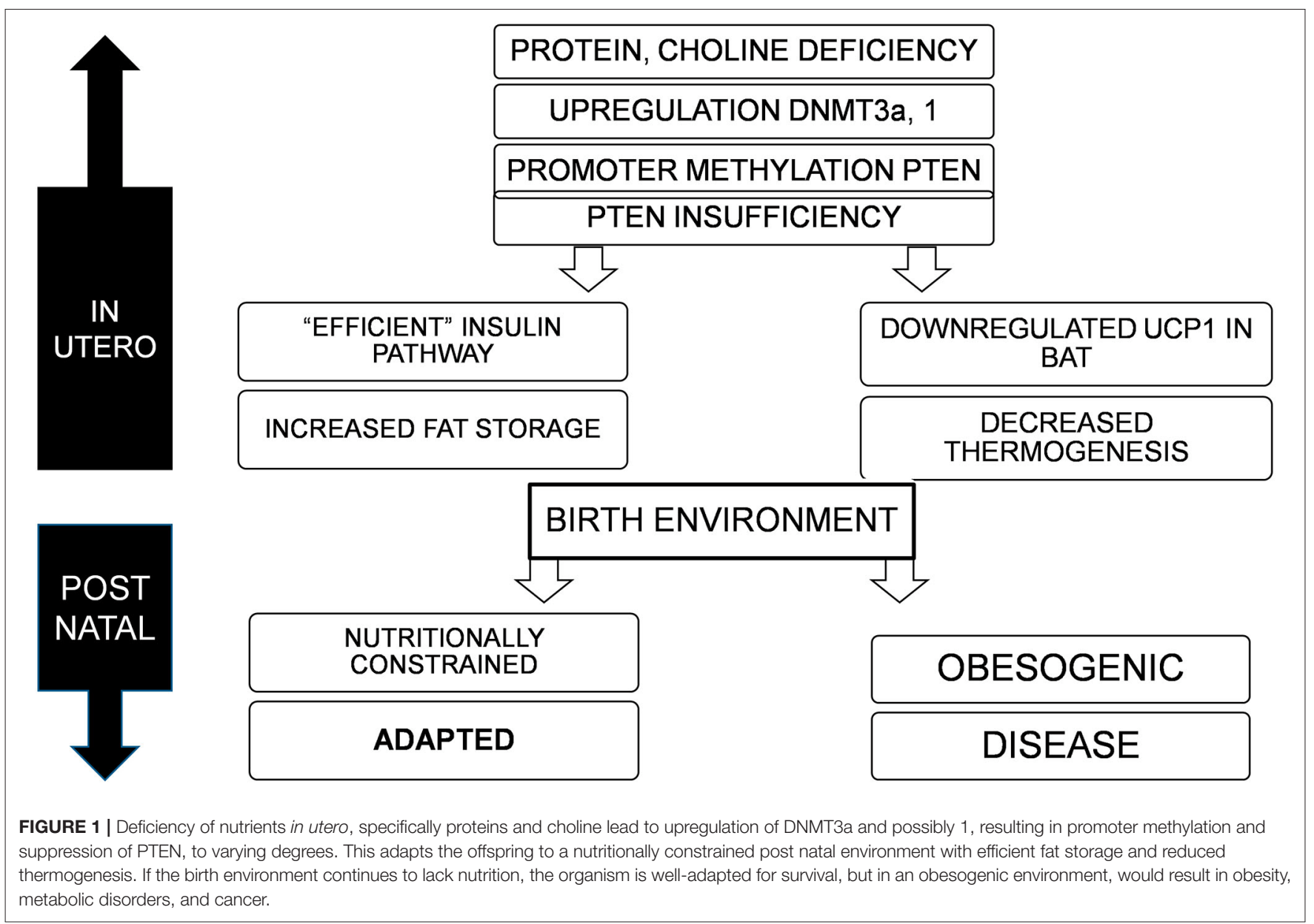

